\title{
Chancellor Wanted! The 2021 German Chancellor Candidates in Context
}

\author{
Ludger Helms
}

Department of Political Science, University of Innsbruck

ludger.helms@uibk.ac.at

\begin{abstract}
The announced farewell of long-term Chancellor Angela Merkel after the 202I Bundestag election, and the ongoing turmoil in the German party system, have created a precarious and unprecedented situation. For the first time ever, there have been three non-incumbent chancellor candidates competing for the job and the legacy of a departing incumbent. Some of the recent developments, such as the nomination of the first Green chancellor candidate and the rifts within the CDU/CSU over their candidate, were notable in their own right. This early assessment puts these developments into perspective by relating the events of 2O2I to historical precedents and key insights of comparative political research.
\end{abstract}

\section{Keywords}

Chancellors, chancellor candidates, Germany, leaders, leadership, parties

\section{Kanzlerln gesucht! Die deutschen KanzlerkandidatInnen 2021 im Kontext}

\section{Zusammenfassung}

Das angekündigte Ausscheiden Kanzlerin Angela Merkels nach der Bundestagswahl 202I hat, im Zusammenwirken mit den jüngeren Verwerfungen im deutschen Parteiensystem, zu einer prekären und einzigartigen Situation geführt: Zum ersten Mal überhaupt konkurrieren drei KandidatInnen um die Nachfolge einer ausscheidenden Kandidatin. Die jüngsten Entwicklungen, darunter insbesondere die Nominierung der ersten grünen Kanzlerkandidatin und die schweren Auseinandersetzungen innerhalb der CDU/CSU, waren bereits für sich betrachtet bemerkenswert. Die vorliegende Bestandsaufnahme rückt diese Entwicklungen in Perspektive, indem sie die Vorkommnisse der ersten I50 Tage des Wahljahres 202I mit historischen Entwicklungen und ausgewählten Befunden aus der Vergleichenden Politikwissenschaft konfrontiert.

\section{Schlagworte}

Kanzler, Kanzlerkandidaten, Deutschland, leaders, leadership, Parteien

The author has declared that no competing interests exist. 


\section{Introduction}

One of the most striking features of the German postwar chancellorship relates to the political longevity of its holders. With just eight chancellors in more than 70 years, the average score is quite impressive by international standards (and even more so by German historical standards of the period I9I9-I933). Adenauer, Kohl and Merkel - three Christian Democrats (Christlich Demokratische Union, CDU) - all governed for more than I4 years, and their combined length of tenure amounts to nearly half a century. Importantly, two of these 'political long-termers' (Kohl and Merkel) featured among the three most recent chancellors. Thus, the upcoming arrival of a new candidate for an office widely considered as the most powerful one in Europe is set to mark a major political event by any standard.

That there would be a change in the office of chancellor in the immediate aftermath of the 202I Bundestag election has been certain ever since Chancellor Merkel, late in October 20I8, announced her decision not to seek re-election as CDU party leader and to step down as chancellor after the completion of her fourth term in office in 2O2I. This unusual move, which reflected the mounting intra-party and public pressure on Merkel at the time, has created an unprecedented situation. Indeed, the 202I Bundestag election marks the first ever occasion in the Federal Republic's history (save the 'founding election' of 1949) with no sitting chancellor seeking re-election. ${ }^{\text {I }}$

Merkel who has long been criticized for not grooming a successor (see Wiliarty 20I8, II6), seemed to have eventually made her peace with the idea of a friendly intra-party handover when informally throwing her weight behind Annegret Kramp-Karrenbauer (a former minister-president of Rhineland-Palatinate and then CDU general-secretary) to become her successor as CDU party leader (and possibly chancellor later on). However, while Kramp-Karrenbauer was actually elected as new CDU party leader in late 20I8, and shortly afterwards also appointed as federal minister of defence, she struggled to establish a reasonable political authority and announced her resignation from the CDU party leadership after just 14 months, in February 2020.

This opened up the field for extensive speculations about Merkel's possible successor in the chancellery, even among those convinced that a continuous hold of the CDU on the chancellorship would be a foregone conclusion. However, this notably immodest expectation eventually began to crumble about three months into

I The resignation of a sitting chancellor as party leader was, however, not unprecedented. In this regard, Merkel followed the example of Chancellor Schröder who stepped down as SPD party leader in 2004 to counter towering intra-party troubles but continued as chancellor. the election year, when the CDU suffered historical defeats in the state elections of Rhineland-Palatinate and Baden-Württemberg that were widely perceived as, at least in part, a voters' dictum on the federal government's increasingly unimpressive 'Corona management'. The Politbarometer survey, published on 26 March 202I reported a historical record loss of 7 percentage points for the Christian Democrats on the previous poll of February (down from 35 to 28 per cent) (Forschungsgruppe Wahlen 202Ia).

This short article seeks to put the 202 I contenders for the German chancellorship, and the features marking their candidacies, into context, relating it to past events in recent German political history as well as to comparative political research on candidates and incumbent political leaders. The next section briefly sketches out the nature of German 'chancellor candidacies,' for which there is no real equivalent in most other parliamentary democracies. The remainder of the paper then assesses the 202I cast of German chancellor candidates. What looks certain already is that coping with the Merkel legacy will prove a major challenge for any of her possible successors. Comparative research suggests that long-term leaders, both at the level of party leaderships and executive office (Horiuchi et al 2015; Helms 2020a, 276), tend to cast particularly long shadows. Other things being equal, the successors to long-term leaders face an earlier political death. ${ }^{2}$ Indeed, at the level of party leaders, Kramp-Karrenbauer's unhappy stint at the CDU party leadership is a glaring case in point. It will be fascinating to see to what extent, and how, this rule applies for the post-Merkel chancellorship as well.

\section{The chancellor candidacy: rules and patterns}

While in parliamentary democracies, in which heads of government are by definition indirectly elected, parties do not necessarily need any lead candidate. Still, virtually all major parties tend to have one on entering the campaign for parliamentary elections. One of the factors that shape the selection of a party's 'chief contender' for the office of head of government is the institutional complexity of a country's political system, and the number of possible candidates that can claim to be particularly worth considering (be it for reasons of widespread public recognition or, more specifically, first-hand experience as political chief executive). The Federal Republic has always been a democratic regime with an advanced level of institutional pluralism, i.e. with a large number of different power-centres and

2 The 'life-shortening effects' of long-term heads of government on their successors are particularly pronounced for candidates coming from the same party, such as Kreisky's successor Fred Sinowatz in Austria or Adenauer's successor Ludwig Erhard in Germany. 
constitutional and other veto-players (Schmidt 2002). A more particular label assigned to the Federal Republic has been that of a 'republic of the state princes' (Steffani 1997), in which the minister-presidents (the heads of government in each of the 16 states), directly and via the Bundesrat, tend to be in an exceptionally powerful position. No less importantly, the internal power structure of the parties clearly reflects Germany's nature as a genuine federation, with the state parties representing regional 'power blocks' at the level of the national party organization. Thus, given the Federal Republic's institutional and political set-up, it is rather likely that there are bids for the German chancellorship from beyond the pool of national party leaders or parliamentary party group leaders in the Bundestag. Indeed, more than half of all non-incumbent chancellor candidates since 1949 have been (former) ministerpresidents in one of the German Länder (see Helms 2020b).

The 'invention' of the chancellor candidacy as a distinct position - for which there has been no real equivalent in Austria and most other parliamentary democracies where the party leaders have been generally considered as the 'natural candidates' for the office of head of government - dates back to the early I960s. In 1960, the SPD elected Willy Brandt, then mayor of Berlin, as their chancellor candidate, who challenged Chancellor Adenauer in the 196I Bundestag election. ${ }^{3}$ Ever since, the major German parties have presented an official 'chancellor candidate' at any Bundestag election. This includes the eight incumbent chancellors either seeking re-election or an electoral 'confirmation' of their incumbency (in fact, Erhard, Kiesinger and Schmidt all came to power by 'inheriting' the office from a departing incumbent from their own party and sought an electoral mandate only later), and a long series of non-incumbent chancellor candidates that challenged the sitting chancellor. Given this extended historical track record, it is perhaps surprising that the practice of televised confrontations between incumbent chancellors and their direct challengers did not emerge before 2002 (involving Chancellor Gerhard Schröder and his adversary Edmund Stoiber), which was because earlier chancellors managed to fight off such demands.

Until 2017, with just one exception, there have been only chancellor candidates related to either the CDU or CSU (Christlich Soziale Union) ${ }^{4}$ or the SPD. These featured

3 Until then, the SPD's party and parliamentary leaders of the early post-war period, Kurt Schumacher and Erich Ollenhauer, had been the party's unchallenged candidates for winning the chancellorship; see Helms (2020b).

4 Given the highly particular relationship of the CDU and CSU, which are formally independent parties - the former running in all states except Bavaria, the latter only in Bavaria - but operate a joint CDU/ CSU parliamentary party group in the Bundestag, the notorious ' $\mathrm{K}$ Frage' is to be decided together; see below.
I4 different SPD chancellor candidates (some of them running more than once, including three candidates that campaigned (also) as incumbent chancellors); nine CDU chancellor candidates (several of them running more than once, including five incumbent chancellors), and two CSU candidates (both non-incumbent). The only exception related to the Freie Demokratische Partei (FPD), a former junior coalition partner at the federal level in both CDU/CSU- and SPD-led governments. In 2002, lacking any realistic chance to secure the chancellorship, the FDP formally elected its party leader Guido Westerwelle as 'chancellor candidate.' This move was, however, from the outset perceived by the other parties and the media as no more than a peculiar PR strategy. The FDP eventually ended up with a meagre 7.4 per cent share of the total vote, and several more years in opposition.

The most important thing to note about the intraparty rules for selecting chancellor candidates is that there have not been any, not even at the level of individual parties. In this regard, the making of chancellor candidates in 2020/202I marked no exception, though the heavy conflicts within the CDU/CSU over their candidate brought this issue to the fore like never before.

\section{The making of three candidates for the post- Merkel chancellorship}

The SPD was the first party to present their chancellor candidate, in August 202O, i.e. 13 months ahead of the upcoming Bundestag election: Finance Minister and 'Vice Chancellor's Olaf Scholz. A year earlier, few would have put any money on Scholz's prospects to secure his party's chancellor candidacy. In August 2019, Scholz had made an unsuccessful bid for the SPD party leadership, which had become vacant by the unhappy resignation of Andrea Nahles - the SPD's sixth party leader in less than I5 years. As strongly suggested by the party leadership bodies, there was a competition among several teams seeking to become the party's new 'dual leadership' (Doppelspitze). Scholz and his running mate, Klara Geywitz, came in second, but lost the run-up election to Saskia Esken and Norbert Walter-Borjans, who became the new SPD party leaders in early December 2019. This result seemed to be not just a personal defeat for Scholz who had been considered by many as the most hopeful and best-placed candidate. It also seemed to signal a significant move of the party to the left. Indeed,

5 Unlike in Austria, there is no constitutionally acknowledged position of Vice Chancellor in Germany. The Basic Law stipulates only that there shall be a deputy to the chancellor who is to be determined by the latter and assumes his or her role only if the chancellor is unable to act. Thus, the title of 'vice chancellor' marks just a popular reference to the deputy in contemporary German political rhetoric. 
for a while it looked as if the SPD was willing to leave the grand coalition government in the middle of the legislative term. This put Scholz in an awkward position as, in his role as 'vice chancellor', he was the party's spearhead in this government. Still, on Io August 2020 the SPD party leadership bodies (Parteivorstand and Parteipräsidium), following a suggestion by Esken and Walter-Borjans, unanimously nominated Scholz as the party's chancellor candidate. ${ }^{6}$

This early nomination, launched more than eight months ahead of the candidate decisions by the other parties (CDU/CSU and the Greens), was apparently designed to avoid the mistakes of the past. In 20I7, the SPD had nominated Martin Schulz - the former president of the European Parliament - about eight months before the Bundestag election, which in retrospective seemed late, or too late, for an 'outsider' to successfully challenge a long-term chancellor seeking re-election.

Given the considerably later nominations of the other parties, Scholz found himself in the strange position of a 'shadow boxer,' desperately waiting for his adversaries to come out. Strangely enough, while being neither a woman nor a CDU candidate, in some ways Scholz shared the most of all three candidates with Chancellor Merkel. This concerned his extended experience as a senior member of the federal government, but barely less so his pragmatic policy-making approach, and his distinctly 'uncharismatic' personality.

Next in line were Bündnis 9o/Die Grünen that publicly announced their first ever chancellor candidate on 19 April 202I. Speculations that the Greens could nominate a chancellor candidate emerged early in 2019, after the party had for the first time advanced to a ' 20 percent plus' share at the national level in various public opinion surveys, temporarily leading the SPD by up to nearly Io percentage points. Obviously, the party's fortunes with the German public fluctuated a lot after the 2017 Bundestag (in which the Greens secured an 8.9 percent share and the SPD a 20.5 percent share of the total vote). However, according to figures by Forsa (202I), the weeks between mid-April 2020 and early June 2020 marked the only period in which the SPD's public support slightly exceeded that of the Greens (at a moderate level of I4 to I7 percent for either party).

The Greens have had an extended history of 'dual party leadership,' with two party leaders sharing the position at the top. The current tandem - Annalena Baerbock and Robert Habeck - has been in office since January 2018 (re-elected in November 20I9). Until the beginning of the election year, public speculations about a possible Green chancellor candidate clearly centred on Habeck. This changed only in the last few weeks before

6 He was officially confirmed as the party's chancellor candidate at a SPD party convention held on 9 May 202I, securing 96.2 per cent of the votes cast. the public announcement of the Green chancellor candidate, when Habeck and Baerbock began to enjoy a perfectly balanced support (tending towards a very slight advantage for Baerbock in the final days before the announcement). After Habeck had mentioned in a talk show in March 202I that if Baerbock were to be willing to take the lead, 'as a woman,' it was to be expected that Baerbock was actually to become the chancellor candidate of her party, which has been by far the most feminist of the major German parties.

The most remarkable thing about Baerbock's public nomination on I9 April 202I was that it - organizationally speaking - emerged completely out of the blue. As the Greens have not only been the most gender-sensitive of all German parties, but also a traditional stronghold of grass-roots intra-party democracy, the party's willingness to leave this key decision up to Baerbock and Habeck alone marked the beginning a new chapter of Green intra-party decision-making. ${ }^{7}$ Ironically, while this extremely elitist procedure could have been criticized for a lack of democratic quality and input legitimacy, the particular circumstances of this nomination - namely the protracted conflict over the CSU/CDU's chancellor candidate (see below) - turned this 'backroom deal' in the eyes of many observers into an exemplary case of responsible intra-party democracy.

Baerbock has held various party leadership functions at the European and state level since 2008, and joined the German Bundestag in 2013. She was not just the only chancellor candidate in $202 \mathrm{I}$ who had no experience in the executive branch (at either state or national level) whatsoever, but also one of the notably few candidates in the Federal Republic's history lacking any executive experience. The only other exceptions relate to the FDP's 'mock chancellor candidate' in 2002 (see above), the ill-fated chancellor candidacy of Martin Schulz (SPD) in 20I7, and the chancellor candidates of the very early post-war period (up to 1957). However, again, the circumstances helped to frame Baerbock's status favourably: In 20II, the state of Baden-Württemberg experienced the appointment of the first Green minister-president in the Federal Republic's history, Winfried Kretschmann, who had no previous executive experience either. In 202I, Kretschmann could not only celebrate his Ioth anniversary in office, but also refer to an impressive track record of having repeatedly been Germany's most popular minister-president. In the early aftermath of Baerbock's nomination, the strategic argument of a 'sweeping newcomer' for the chancellorship curiously played no major role in the Greens' marketing of their candidate, however.

\footnotetext{
7 While Baerbock still had to be confirmed by a Green party convention scheduled for mid-June 202I, this was expected to be a mere formality.
} 
Rather, senior party officials hastened to point out that Baerbock was to be supported by her fellow party leader Habeck who had some previous executive experience (as minister of energy, agriculture, environment and rural areas, and deputy minister-president in the state of Schleswig-Holstein, 2012-2018). What became clear early on was that Baerbock's nomination would not automatically boost her popularity; in fact, by the end of May 202I she continued to trail behind Habeck in the popularity ranking of Germany's ten most important German politicians, and even suffered her worst score since joining that league several weeks earlier (see Forschungsgruppe Wahlen 202Ib).

The fight for the CDU/CSU chancellor candidacy marked, in many ways, the most spectacular event of the 2O2I pre-election campaign - all the more so as many had expected the election of Armin Laschet as CDU party leader in January 2O2I to pre-determine the party's decision on the CDU/CSU chancellor candidate. ${ }^{8}$ On I6 January 202I, Laschet won the online run-up election against Friedrich Merz (a former CDU/CSU parliamentary party group leader-turned-businessman, and a committed critic of Chancellor Merkel) with 52I to 466 votes. In the first ballot, Laschet had come in only second, with 380 votes, after Merz ( 385 votes), but well ahead of Norbert Röttgen (a former minister in the Merkel cabinet and current chair of the Bundestag's Committee on Foreign Affairs; 224 votes). In the confirming postal vote, whose results were announced on 22 January 202I, Laschet received 796 votes, i.e. 83.35 per cent. ${ }^{9}$

Speculations about a possible chancellor candidacy by the CSU party leader and minister-president of Bavaria, Markus Söder, emerged as early as late 2019 countered by Söder's constant assurances that his place was in Bavaria. Since the end of 2020, at the latest, however, it became increasingly manifest that a bid from Munich was on the cards. Söder's appeal was hardly that of a proven 'election winner.' In fact, after he had gone out of his way to oust Horst Seehofer as CSU party leader

8 The position of CDU party leader has indeed been widely perceived to be effectively equipped with a first choice option for the chancellor candidacy. However, this is not quite what the historical record suggests: There were just five occasions after the election of Konrad Adenauer in 1949 on which the CDU/CSU had to nominate a non-incumbent chancellor candidate. On only three of them (Barzel in 1972 , Kohl in 1976, and Merkel in 2005) the CDU/CSU nominated a CDU candidate, while on two others (Strauß in 1980, and Stoiber in 2002) a CSU candidate prevailed.

9 Laschet, who became minister-president of North Rhine-Westphalia in 2017 by leading the CDU to a spectacular victory over the SPD and their exceptionally popular minister president, Hannelore Kraft, had not joined the race for the CDU party leadership in 20I8. With the next regular Bundestag election nearly three more years away, it seemed less sure back then if the CDU party leadership position would actually be a safe pathway to the chancellor candidacy, and Laschet was understood to be unwilling to invest his political capital for a mere party position. and minister-president of Bavaria in 2018, Söder chaired over the weakest electoral showing of the CSU since 1950, followed by the formation of a CSU-led coalition government (only the second one in more than half a century). Instead, Söder's key resource was his immense personal popularity that developed over the course of the Corona pandemic. Söder increasingly became the embodiment of a committed leader and gifted 'crisis manager' (even though the reported Covid-I9 figures for Bavaria were by no means significantly better than for many other parts of the country).

For achieving this status, it proved an exceptionally fortunate coincidence for Söder that he was the chair of the Prime Ministers' Conference of the German states (Ministerpräsidentenkonferenz) from September 2019 through September 2020, and its deputy chair after that - positions not to be filled by a competitive election among the minister-presidents but staffed according to a predetermined order established in 1990. Thanks to that position, Söder sat next to Merkel at the frequently held joint press conferences, which provided him not just with a maximum amount of public visibility but also allowed him to perform the role of an authorized chiefcommentator on the nation-wide pandemic-related developments in the media. His deputy chair position was to prove all the more useful, as from October 2020 the third member of the 'Big Three' (alongside Merkel and Söder himself) was Minister-President Michael Müller of Berlin (SPD), repeatedly ranked as the most unpopular of all incumbent German minister presidents. Moreover, Söder advanced his status by a long series of skillfully handled appearances in television interviews and as a frequent participant in televised talk shows.

The critical stage of the competition between Laschet and Söder began on II April 2021, when they declared in a joint press statement that both of them would be willing to accept the CDU/CSU chancellorship. As it had been known for weeks, if not months, that both would-be candidates would consult with each other at length and then communicate their shared decision to the public, this statement actually indicated that the attempt to peacefully agree on a joint solution, as between Merkel and Stoiber in 2002, had failed. Söder hastened to add that his offer was valid to the extent that there was reasonable support for his candidacy from 'the big sister', the CDU. However, notwithstanding this rhetorical gesture, it remained immensely uncertain what it would take to cause Söder to withdraw his candidacy.

Notwithstanding the formal dividing lines between the CDU and CSU, the showdown of April 202I (and beyond) was, however, no less of an intra-party CDU conflict. While Laschet could report to the public on I2 April 202I that he enjoyed the full backing of the Bundesvorstand and the Präsidum of his party, the real challenge was to take place only in the days to follow. On 
I3 April, Laschet and Söder appeared before the CDU/ CSU Fraktion in the Bundestag - a meeting demanded by the Söder camp, whose proceedings indicated the existence of much support for Söder also amongst many CDU members. Over the following days, the possibility of a formal vote being taken in the Fraktion loomed over Laschet's candidacy, whose real meaning can be realized only by recalling the events of summer $1979 .{ }^{10}$

To forestall a vote in the CDU/CSU Fraktion, Laschet convened a meeting of the CDU party bodies on 19 April 2021. After six hours of heated debate, the news broke that the CDU leadership had agreed with a broad majority on Laschet as their chancellor candidate. However, in contrast to the supposedly consensual mood a week earlier, a formal vote was taken in which 3I members opted for Laschet, but nine against him, with six others abstaining. The opposition to Laschet came mainly, if not exclusively, from the eastern states. The even more important divide, however, concerned that between the CDU party leadership circles, and the CDU grassroots organizations, many of which reportedly voiced a strong preference for Söder, as did the Junge Union (the CDU's youth organization). While the early hours of 20 April were filled with anxious speculation if Söder was to accept this outcome as a reasonably strong backing for Laschet (on which he had conditioned his withdrawal), he accepted this decision in the first sentence of his public statement at noon the same day, and assured his former opponent of his unconditional support.

The weeks after the decision nevertheless provided a wealth of hints that Söder could effectively become something of a 'shadow chancellor candidate' a backseat driver calling the shots rather than serving the team in the 'Laschet for chancellor' campaign. Any realistic scenario of a future government with Laschet as chancellor seemed to include a major potential for a re-emergence of deep 'intra-Union' conflicts, which had marked the years between 2015 and 2018, with Chancellor Merkel and CSU party leader Horst Seehofer as the protagonists.

While there can be no doubt that Laschet was, compared to Söder, in many respects the 'weaker' or

IO In the run-up to the I980 Bundestag election CDU party leader Helmut Kohl, who was widely unpopular at the time, decided not to run and make room for another candidate from the CDU leadership circles, then minister-president of Lower-Saxony, Ernst Albrecht (the father of the current European Commission President, Ursula von der Leyen). However, the CSU insisted on their own candidate, CSU party leader and Bavarian Minister-President Franz-Josef Strauß. After weeks of intense infights, the CDU and CSU party leaderships agreed that the candidate should be determined through a secret ballot in the CDU/CSU Fraktion. On 2 July 1979 Albrecht lost this ballot in the Fraktion with IO2 to I35 votes to Strauß, who eventually led the CDU/CSU to their by then greatest election defeat in the I980 Bundestag election. 'softer' candidate, a context-sensitive assessment of his candidacy would not be complete without considering the personality-related features of the German chancellorship. While being presented by the media as essential qualities of effective national political leaders, charisma and vigorousness have not been the defining characteristics of many former German chancellors. What Ansell and Fish referred to as 'noncharismatic personalism,' a label tailored to capture the nature of Helmut Kohl's leadership (Ansell/Fish 1999), describes a skill-related qualification of German chancellors more generally. In fact, the past decades demonstrated that in the particular setting of post-unification Germany, successful leadership is more about 'moderating' than 'directing', and that gestures of 'strong leadership' ultimately tend to prove a source of weakness and enhanced vulnerability rather than strength (see Helms 2016). In a newly emerging context, in which future federal governments are likely to be either a 'grand coalition 2.0' (CDU/CSU-Greens) or a three-party coalition, if not a minority government, the skills of a patient moderator will be more needed than ever.

\section{From candidates to coalitions}

Many opinion polls published in the closing days of April and early May 202I showed the CDU/CSU and the Greens operating right on par - a notable fact in its own right (given the results of the 2017 Bundestag election, in which these two parties secured 32.9 and 8.9 per cent of the total vote respectively). While some surveys pointed to a slight lead of either party, there was widespread agreement that the chances for the SPD to win the chancellorship looked rather bleak - even though in a public opinion survey on the preferred chancellor, with all three candidates pitted against each other, Scholz fared slightly ahead of both Laschet and Baerbock (see Forschungsgruppe Wahlen 2O2Ib). According to the same source, at that stage both a coalition between CDU/ CSU and the Greens, and a coalition between the Greens, the SPD and the FDP were able to secure a parliamentary majority - in striking contrast to the incumbent CDU/ CSU-SPD government. All this underscored the ongoing dynamics of change within the party system ${ }^{\text {II }}$, prompting CDU/CSU sources, including Markus Söder, to rule out that the Christian Democrats could be available for a junior coalition partner role.

II Complementing such projections of the electoral performance of individual parties and possible coalitions, a survey published on I7 May 202I documented a historically unprecedented desire for a change of government (6I.5 per cent), and major policy change (supported by about two-thirds of respondents), among the German public; see Frankfurter Allgemeine Zeitung 2O2I. 
As the formation of governing coalitions at the federal level has become significantly more imponderable and time-consuming over the years ${ }^{12}$, forecasting the possible emergence of future coalitions and their leaders ahead of the polls has increasingly turned into a major scholarly gamble. The government-building experience in the aftermath of the 2017 Bundestag election with its many paradoxical twists and turns provided a major lesson for the public and the profession alike (Hornung et al. 2020). ${ }^{13}$ Still, as the way political leaders come to office tends to shape their perceived performance in office to a considerable extent (see Weller 2014, 494), even this early and cursory assessment of the first steps of the making of Merkel's supposed successor should not fail to contribute its share to a deeper understanding of the evolving German chancellorship.

\section{References}

Ansell, Christopher K./M. Steven Fish (1999), The Art of Being Indispensable: Noncharismatic Personalism in Contemporary Political Parties, in: Comparative Political Studies, Vol. 32(3), 283-312.

Bundestag (2018), Datenhandbuch zur Geschichte des Deutschen Bundestages, Berlin 2018, Internet: https://www.bundestag.de/datenhandbuch (access: 21.05.202I).

Forsa(202I), Wenn am nächsten Sonntag Bundestagswahl wäre..., Internet: https://www.wahlrecht.de/ umfragen/forsa.htm (access: 21.05.202I).

Forschungsgruppe Wahlen (2O21a), Politbarometer März 202I, 26.03.202I, Internet: https://www. forschungsgruppe.de/Umfragen/Politbarometer/ Archiv/Politbarometer_202I/Maerz_2O2I/ (access: 22.05.202I).

Forschungsgruppe Wahlen (2021), Politbarometer Mai II 202I, 21.05.202I, Internet: https://www. forschungsgruppe.de/Umfragen/Politbarometer/ Archiv/Politbarometer_2O2I/Mai_II_2O2I/ (access: 22.05.202I).

I2 The aftermath of the Bundestag elections of 2013 and 2017 both set new records: 86 and $\mathrm{I}$ 7 I days respectively. By contrast, the average score for the six previous government formations (I990 through 2009) was just 39.2 days; see Bundestag (20I8, chapter 6.7, p. 2)

I3 Even before the recent destabilization of the German party system, however, the making of German chancellors has not been quite as straightforward as widely suggested. Specifically, under certain conditions, the largest party may go empty. In 1969, the CDU/CSU became the largest party in the Bundestag election of that year, but the chancellery nevertheless went to the Social Democrats who managed to win the FDP as their junior coalition partner. This marked just the first of three occasions on which the CDU/CSU was the largest party in the Bundestag but still failed to secure the chancellorship (1969, I976, and I980).
Frankfurter Allgemeine Zeitung (202I), Mehrheit der Deutschen wünscht sich Regierungswechsel, I7.05.202I, Internet: https://www.faz.net/aktuell/ politik/inland/mehrheit-der-deutschen-wuenschtsich-regierungswechsel-I7344863.html (access: 23.05.202I).

Helms, Ludger (2016), The Politics of Leadership Capital in Compound Democracies: Inferences from the German Case, in: European Political Science Review, Vol. 8(2), 285-310.

Helms, Ludger (2O2Oa), Heir Apparent Prime Ministers in Westminster Democracies: Promise and Performance, in: Government and Opposition, Vol. 55(2), 260-282.

Helms, Ludger (2020b), Spitzenkandidaten beyond Westminster: Comparing German and Austrian Chancellor Candidates, in: Parliamentary Affairs, Vol. 73(4), 808-830.

Horiuchi, Yusako/Matthew Laing/Paul 't Hart (2015), Hard Acts to Follow: Predecessor Effects on Party Leader Survival, in: Party Politics, Vol. 2I(3), 357-366.

Hornung, Johanna/Robin Rüsenberg/Florian Eckert/Nils C. Bandelow (2020), New Insights into Coalition Negotiations - The Case of German Government Formation, in: Negotiation Journal, Vol. 36(3), 33I-352.

Schmidt, Manfred G. (2002), The Impact of Political Parties, Constitutional Structures and Vetoplayers on Public Policy, in: Keman, Hans (ed.), Comparative Democratic Politics, London: Sage, I66-I84.

Steffani, Winfried (1997), Die Republik der Landesfürsten, in: Steffani, Winfried (ed.), Gewaltenteilung und Parteien im Wandel, Wiesbaden: VS Verlag für Sozialwissenschaften, 56-88.

Weller, Patrick (2014), The Variability of Prime Ministers, in: Rhodes, R.A.W./Paul 't Hart (eds.), The Oxford Handbook of Political Leadership, Oxford: Oxford University Press, 489-502.

Wiliarty, Sarah Elise (2018), The state of the CDU, in: German Politics 27(I): II3-II8.

\section{Author}

Ludger Helms has been Professor of Political Science at the University of Innsbruck since 2008. His research interests focus on comparative political institutions, executive politics, and German and West European politics and society. He has published extensively in those fields. 